\title{
Parásitos intestinales
}

\section{Toxoplasmosis}

\section{Inhibición de la apoptosis en astrocitos infectados con Toxoplasma gondii}

Carla Contreras-Ochoa ${ }^{1,2,3}$, Alfredo Lagunas-Martínez¹, Jaime Belkind-Gerson ${ }^{2}$, Dolores Correa ${ }^{3}$

${ }^{1}$ Centro de Investigación Sobre Enfermedades

Infecciosas, Instituto Nacional de Salud Pública,

Cuernavaca Morelos, México

${ }^{2}$ Laboratorio de Medicina Regenerativa, Centro de Investigación en Salud Poblacional, INSP, México

${ }^{3}$ Laboratorio de Inmunología Experimental, Instituto Nacional de Pediatría, México, D.F., México

Introducción. Toxoplasma gondii es un protozoario intracelular que se replica dentro de la célula huésped. Actualmente existe información controversial sobre el efecto del parásito sobre la apoptosis de la célula infectada en diversos tipos celulares, particularmente en el cerebro, órgano blanco preferencial de este parásito.

Objetivo. Evaluar el efecto de la infección de $T$. gondii sobre la apoptosis en astrocitos de cerebro in vitro.

Metodología. Los astrocitos de ratón neonato se infectaron con taquizoítos de $T$. gondii cepa $\mathrm{RH}$. Se estandarizó un modelo de apoptosis en astrocitos con cisplatino (fármaco antineoplásico). Se evaluó la expresión de genes antiapoptóticos (Bcl-2 y Survivina) y proapoptóticos (IKBa) por RT-PCR; y de proteínas clave en la apoptosis: caspasa 3 (efectora) y PARP-1 (blanco de caspasa 3) por inmunoblot; así como la fragmentación de núcleos mediante tinción con DAPI y microscopía confocal.

Resultados. T. gondii disminuyó parcialmente la expresión de los genes Bcl-2 y survivina entre las 4 y 18 horas después de la infección, recuperándose a las 24 horas, pero no provocó cambios en el gen IkBu ni en la caspasa 3. La infección con el parásito no indujo la fragmentación de PARP-1, más bien la inhibió parcialmente entre los 30 minutos y las 4 horas. Además, inhibió la fragmentación nuclear de la célula huésped, inducida por el cisplatino entre 12 y 48 horas de infección.

Conclusiones. La infección con $T$. gondii no induce la apoptosis en astrocitos de ratón; más bien previene la muerte celular inducida por un estímulo apoptótico, lo que puede favorecer su persistencia. Esta información contribuye a entender la histopatología de la enfermedad en el sistema nervioso central.

\section{Aislamiento de una nueva cepa avirulenta de Toxoplasma gondii nativa de Colombia}

Graciela Juez¹, Myriam Andrea Hortúa², Bárbara H. Zimmermann²

${ }^{1}$ Universidad Manuela Beltrán, Bogotá, D.C., Colombia

2 Universidad de los Andes, Bogotá, D.C., Colombia

Introducción. Toxoplasma gondii es un parásito que infecta al humano mediante el consumo de vegetales, aguas y carnes contaminados. Algunos trabajos reportan como fuente importante de $T$. gondii en humanos, el consumo de carnes infectadas con quistes y, en Colombia, el cerdo es la especie con mayor presencia de este patógeno. Debido a la prevalencia en algunas regiones de Colombia, este trabajo pretendió caracterizar parcialmente una cepa avirulenta de $T$. gondii aislada de carne de cerdo proveniente del departamento del Meta.

Materiales y métodos. Se hizo una mezcla con tres tipos de tejido de cerdo, lengua, corazón y músculo; luego se dividió esta muestra en una parte para inocular ratones y otra para pruebas de detección molecular. Se practicó una PCR anidada para amplificar el gen $B 1$ y el locus SAG-2 3' y 5', histoquímica para visualizar quistes en tejido cerebral de ratón, Western blot para ratones inoculados con la muestra de cerdo y, finalmente, se hizo la caracterización preliminar del gen $B 1$ mediante RFLP.

Resultados. En muestras de uno de tres cerdos analizados se detectó la presencia de $T$. gondii, usando iniciadores de PCR para el gen $B 1$ y el locus SAG-2 3' y 5'. Se observaron quistes en tejido cerebral de ratón infectado con material del cerdo. En el Western blot se detectaron anticuerpos anti- $T$. gondii en el suero del ratón infectado y, en la caracterización por RFLP del gen B1, se observó falta de sitios de restricción para la enzima Pml-I, lo que indica que la cepa es avirulenta aunque aparentemente tiene parte de la secuencia del gen $B 1$ característico de una cepa de tipo I. Se requieren estudios de tipificación más detallados 
para definir su perfil genético.

Conclusiones. En este trabajo se logró detectar una cepa de $T$. gondii proveniente del departamento del Meta, avirulenta con perfil por RFLP del gen B1 de tipo I.

\section{Detección y viabilidad de T. gondii en muestras de carne curada para consumo humano}

M. M. Gómez-Samblas, G. González-González, L. M. de Pablos, T. Cruz-Bustos, A. Osuna Instituto Biotecnología, Grupo de investigación Bioquímica y Parasitología Molecular, Departamento De Parasitología, Universidad de Granada, España

Introducción. La toxoplasmosis es una enfermedad zoonótica producida por un protozoo Apicomplexa, Toxoplasma gondii, de multiplicación intracelular obligada y que presenta una amplia distribución a nivel mundial.

La ingestión de carne poco cocida puede dar lugar a la infección por $T$. gondii en los seres humanos. El desarrollo de estrategias eficaces de prevención se ve obstaculizada por la falta de información cuantitativa sobre el nivel de contaminación de distintos tipos de carne.

El objetivo del presente trabajo fue desarrollar un método para la detección y cuantificación de $T$. gondii en productos cárnicos sometidos a curación para consumo humano. $Y$ posteriormente, aislar y analizar la viabilidad del parásito mediante bioensayos en ratón.

Material y métodos. Se preparó un extracto de ADN libre desde 100 gramos de carne, captura magnética del ADN de $T$. gondii y PCR cuantitativa en tiempo real, con sondas para amplificar un elemento repetido de $529 \mathrm{pb}$. El método de PCR se practicó mediante sondas taqman.

Para el bioensayo se utilizó un ratón por muestra positiva para PCR. La digestión de la carne se hizo con pepsina ácida, que posteriormente, con una solución de antibióticos, se le inyectó al ratón por vía intraperitoneal. Después de cinco semanas de la inoculación, se sacrificó el ratón. Se analizó el cerebro con PCR cuantitativa en tiempo real.

Resultados. Los resultados obtenidos con el método PCR mostraron un porcentaje de positivos de $20 \%$ para un total de 136 muestras de carne curada, de las cuales el $15 \%$ fueron positivas en el bioensayo con ratones.

Conclusiones. Se ha demostrado que $T$. gondii está presente en este tipo de muestras cárnicas, siendo necesario algún proceso en el proceso de curado que sea capaz de eliminar la viabilidad de dicho parásito.

$$
\text { - }
$$

\section{Cinética de invasión de las cepas $\mathrm{RH}$ y} ME49 de Toxoplasma gondii en células endoteliales humanas

L. B. Ortiz-Alegría, I. Cañedo-Solares, M. Calzada-Ruiz, H. Luna-Pastén, D. Correa

Laboratorio de Inmunología Experimental, Instituto Nacional de Pediatría, México

Introducción. Toxoplasma gondii puede causar infección congénita. La invasión de las células endoteliales de la placenta es una manera de transmisión al bebé. Existen tres linajes predominantes de T. gondii: I, II y III; los primeros, son virulentos en ratones y se han identificado en toxoplasmosis congénita en España y México. Se desconoce la diferencia en la cinética de invasión a las células endoteliales entre linajes, por lo que se hicieron ensayos comparativos entre la cepa $\mathrm{RH}(\mathrm{I})$ y la ME49 (II), usando una línea celular humana de microvasculatura (HMEC-1).

Materiales y métodos. Los taquizoítos se adicionaron a las HMEC-1 en una proporción de 10:1 y se incubaron durante diferentes tiempos (30 minutos a 4 horas) en presencia o ausencia de una mezcla de antibióticos/antifúngico; se fijaron y se tiñeron con Wright; se cuantificaron los parásitos en el sobrenadante, el número de células infectadas, las vacuolas parasitóforas por célula y los parásitos por vacuola.

Resultados. El porcentaje de células infectadas con ambas cepas aumentó con el tiempo; sin embargo, a los 30 y 60 minutos fue mayor con la ME49 ( 45 \%) que con la RH ( 20\%). El número de vacuolas por célula en ambas condiciones fue similar ( $\leq 5)$ para $\mathrm{RH}$; mientras que, para ME49 fue mayor en ausencia de la mezcla de antibióticos ( $\leq 26$ Vs. $\leq 5$, respectivamente). En todos los casos hubo un parásito por vacuola.

Conclusiones. La cinética de infección fue diferente entre las cepas RH y ME49 de T. gondii, en cuanto al número de vacuolas (parásitos totales) por célula. Además, la mezcla de antibióticos/antifúngico tuvo influencia sobre el grado de infección de ambas cepas.

Este trabajo fue presentado en: The 86th Annual Meeting of the American Society of Parasitologists, en junio de 2011. 